\title{
Comparative study of fetal and maternal outcomes of prelabour rupture of membranes at term
}

\author{
Janhavi Mukharya ${ }^{1}$, Simmi Mukharya ${ }^{2}$ \\ ${ }^{1}$ Department of Obstetrics and Gynecology, AVBRH, Sawansi Meghe, Wardha, Maharashtra, India \\ ${ }^{2}$ Department of Obstetrics and Gynecology, Ganesh Memorial Hospital, Wardha, Maharashtra, India
}

Received: 20 October 2016

Revised: 15 November 2016

Accepted: 17 November 2016

\author{
*Correspondence: \\ Dr. Janhavi Mukharya, \\ E-mail: janvimukharya@gmail.com
}

Copyright: $\odot$ the author(s), publisher and licensee Medip Academy. This is an open-access article distributed under the terms of the Creative Commons Attribution Non-Commercial License, which permits unrestricted non-commercial use, distribution, and reproduction in any medium, provided the original work is properly cited.

\begin{abstract}
Background: Premature rupture of membranes (PROM) refers to the loss of integrity of membranes before onset of labor, with resulting leakage of amniotic fluid and establishment of communication between the amniotic cavity and the endocervical canal and vagina. The aim of the study was to compare the fetal and maternal outcomes of actively managed and expectantly managed term PROM in a rural setup.

Methods: In this prospective study we included 200 women with diagnosed prelabour rupture of membranes. All women had gestational age $>37$ weeks and $<41$ weeks with singleton pregnancy and vertex presentation. Study excluded all patients with previous uterine scar or with any medical or surgical disorder. They were randomly divided in two groups with 100 women each: Group A which was induced with PGE1 or oxytocin depending on their cervical score and Group E which was managed expectantly and late induction after 24 hours was done. Both the groups were given intravenous antibiotics. They were evaluated on the basis of fetal and maternal outcomes.

Results: In this study we found that $70 \%$ women who were managed expectantly went in labour within 24 hours of PROM. But PROM to delivery interval was longer in expectantly managed as compared to actively managed or induced group. Rate of cesarean was more in induced group but was statistically insignificant when compared in both the groups. So was NICU admission more in expectant group but was statistically insignificant when compared in both the groups.

Conclusions: Expectant managed can be done in patients with term PROM to reduce the cesarean rate in rural setup. There was no significant difference in maternal and fetal outcomes of the management.
\end{abstract}

Keywords: Fetal and maternal outcomes, PGE1, PROM

\section{INTRODUCTION}

Premature rupture of membranes (PROM) refers to the loss of integrity of membranes before onset of labor, with resulting leakage of amniotic fluid and establishment of communication between the amniotic cavity and the endocervical canal and vagina. ${ }^{1}$

Prelabor rupture of membranes is a matter of major concern for all obstetricians as it is associated with high fetal morbidity and mortality and maternal morbidity and mortality sometimes.

The majority (90\%) of prelabor rupture of membranes (PROM) occurs in women who are at term Zamzam, and PROM at term occurs in 8 per cent of all births (Hannah et al. ${ }^{2-4}$ In the majority of patients at term, labor will occur spontaneously within the first 24 hours following amniorrhexis. 
PROM occurs when intrauterine pressure overcomes membrane resistance. This happens as a result of weakening of membrane either congenital or acquired (smoking and vitamin $\mathrm{C}$ deficiency), or because of damaging factors, either mechanical (amniocentesis or amnioscopy) or physical-chemical damage by infection (trichomonas, group B Streptococci, bacterial vaginosis, etc). Failure of mechanical support such as cervical dilatation can lead to PROM, favouring bacterial contamination as well. ${ }^{1}$

Interestingly, at term, PROM can be a physiological variation rather than a pathological event. ${ }^{5}$

The major question regarding management of these patients is whether to allow them to enter labor spontaneously or to induce labor as there is a major maternal risk of intrauterine infection which is a most serious complication associated with PROM for the mother and the neonate. The risk of chorioamnionitis with term PROM has been reported to be less than 10 per cent and to increase to 24 per cent after 24 hours of PROM. These points out the importance of appropriate management strategies for PROM at term.

The key to the management depends on the accurate assessment of gestational age, likelihood of infection, duration of latent phase and the availability of NICU facilities.

There is a general agreement that the term pregnant patients with PROM should be delivered to avoid infection to both mother and the infant as the dangers of infection goes on increasing with prolonged latent phase. But early interference may increase the incidence of caesarean section.

Neonatal morbidity will also be increased because of the mechanical difficulties encountered with delivery, either by vaginal or abdominal route due to reduced volume of amniotic fluid. In the event of non-induction of labor in PROM, there may be good uterine contractions but reduced amount of liquor causes failed progression and consequently dry labor followed by rupture uterus.

According to Flenady V, where membranes rupture in latent phase, latent phase is longer but the remaining portion of curve is uninfluenced. ${ }^{6}$ If induction is attempted with intravenous oxytocin drip, the frequency of failed induction and subsequent caesarean delivery approaches $30-40 \%$ and protracted labor increases the risk of maternal and neonatal infection. Conversely if women are observed expectantly to allow the cervix to ripen and labor to begin spontaneously, infection, umbilical cord prolapse or compression of the cord may occur, these in turn lead to an increased frequency of caesarean delivery, and if women are hospitalized, increased expenses is incurred. The specific dilemma involves how best to treat patients with PROM.
Thus the frequency of term PROM and the questions that still exist with regard to optimal management of these cases justify the need to carry out this randomized study to evaluate and compare the results of active and expectant management of term PROM. Hence, there is a need to assess the effects of planned early birth versus expectant management for women with prelabor rupture of membranes at term on fetal, infant and maternal wellbeing.

The aim of the study was to compare the effects of expectant and active management of pre-labor rupture of membranes at term on feto-maternal outcome in a rural setup

The objective of this study was to study the effect of expectant management on feto maternal outcomes in term PROM. To study the effect of active management on feto maternal outcomes in term PROM. And to study and compare the of feto-maternal outcome expectant and active management of PROM at term.

\section{METHODS}

A prospective and observational study was conducted at the department of Obstetrics and Gynecology Acharya Vinoba Bhave Rural Hospital of Jawaharlal Nehru Medical College, Sawangi (Meghe), Wardha 442004, Maharashtra over a period of 24 months from October 2014 to August 2016. 200 Patients with diagnosis of pre labor rupture of membranes with term gestation (37 - 40) weeks having PROM irrespective of gravidity and parity Gestational age assessment was done by LMP - Naegle's formula

Type equation here.

The formula used for sample size $\mathrm{n}=\mathrm{x}^{2 *} \mathrm{~N} * \mathrm{P}(1-\mathrm{P}) / \mathrm{C}^{2}(\mathrm{~N}-$ $1)+\mathrm{x}^{2} * \mathrm{P}(1-\mathrm{P})$

Where,

- $\mathrm{x}^{2}=$ chisquare tabulated value at $5 \%$ level of significance $=3.84$

- $\mathrm{C}=0.05=$ desired level of error

- $\mathrm{N}=$ total no. yearly pts with confirmed pre labor rupture of membranes 60

- $\mathrm{P}=0.50$

- $\quad$ Thus $n=54.7$

\section{Inclusion criteria}

Women at term gestation (37 - 40) weeks having PROM irrespective of gravidity.

- Gestational age assessment was done by

LMP - Naegle's formula

Ultrasound. 
- $\quad$ Singleton pregnancy

- Pregnancy with vertex presentation.

\section{Exclusion criteria}

- Women less than 37 Weeks of gestation and more than 41 Weeks of gestation

- Women with medical disorders

- Women with obstetric high risk factors like diabetes, Pregnancy induced hypertension, heart disease complicating pregnancy, antepartum hemorrhage etc

- Women with congenital anomalous fetus, abnormal presentation, intra uterine death.

The Ethical committee clearance was taken before initiation of the study. All term pregnant women reporting with complaints of watery vaginal discharge, fulfilling above inclusion criteria were included in the study. An informed written consent was taken. All the information and results were recorded in the pre-designed proforma.

Thorough history was taken and clinical examination done. Demographic information, height and weight were recorded to calculate the body mass index. Speculum examination with all aseptic precautions was done to observe for pooling of liquor, Nitrazine test was done. Vaginal examination was done to know the length, dilatation and effacement of the cervix and station of presenting part. Bishop scoring was done.

Gestational age was determined from last menstrual period (LMP) and/or early ultrasonography.

An obstetric ultrasonography was done for gestational age, presentation of baby, any congenital anomaly and baby weight, placental grading, amniotic fluid index.

Blood sample was collected for complete blood counts and $\mathrm{Rh}$ typing and other routine investigations.

Body mass index was calculated by using the formula:

$$
B M I=\frac{\text { Weight }(\text { in } K g)}{\text { Height }(\text { in meter } \text { square })}
$$

Less than $19.5 \mathrm{~kg} / \mathrm{m}^{2}$ were underweight, $20-25 \mathrm{~kg} / \mathrm{m}^{2}$ was normal and $>25 \mathrm{~kg} / \mathrm{m}^{2}$ was obese.

\section{Management}

Women having confirmed diagnosis of PROM were randomly allotted to either active management or expectant management by random sampling. Informed consent was taken for either management.

\section{Active management}

After assessment of pelvis and Bishop's Score, if cervix unfavorable i.e 0-5, induction with PGE1 given $25 \mathrm{mcg}$ orally 6 hourly and was repeated till favorable bishop's score was achieved followed by augmentation with oxytocin drip was practiced.

If favorable i.e. 6 -13 of bishops score, Oxytocin drip 2-5 units in $500 \mathrm{ml} \mathrm{PL}$ was given and titrated till adequate contraction rate was achieved i.e. 3 contractions in 10 min each lasting for 45 seconds. If labour had not supervened drip is again repeated after 2 - 4 hours.

\section{During active management}

Monitoring once in every $1 / 2$ hours for maternal pulse rate, uterine action with descent of head, fetal heart sounds rate was noted. Per vaginal examination done and temperature was recorded once in 4 hours in active labour.

\section{Expectant management for 24 hours}

After admitting a woman with PROM, vitals recorded every 4th hourly. Abdominal examination done for uterine action and descent of head. Repeated per vaginal examinations were avoided. Pad given for observation and for any meconium stained leak or foul smelling infected discharge. Prophylactic antibiotic given. Maternal pulse rate and fetal heart sounds uterine action monitored every half an hourly. Expectant management is abandoned in the following conditions. Signs and symptoms of chorioamnionitis: fever of more than $100 \mathrm{~F}$, maternal tachycardia more than 100, fetal tachycardia more than 160 beats per minute, uterine tenderness, foul odor of amniotic fluid and maternal leucocytosis. Fetal distress was fetal heart rate less than 110 and more than 160 beats per minute. Mode of delivery was noted as

- Spontaneous onset of labor, delivered vaginally

- Outlet or vacuum

- Caesarean section.

In few patients who went into spontaneous active labor and then needed augmentation of labor was done with oxytocin drip 2- 5 units in 500ml PL was given. Titration was done till there is optimal response.

The mother was followed up in the puerperium for one week for any signs and symptoms of morbidity high fever, foul smelling lochia, wound gaping etc. By maintaining 4th hourly - temperature, pulse rate chart. In the presence of fever other causes like breast engorgement, Respiratory tract infection and prior urinary tract infection were excluded. The smell and colour of lochia were noted. Rate of involution of uterus and duration of hospital stay was also noted. 


\section{Neonatal outcome}

The newborn babies were examined for APGAR score at 1 min of birth. Their birth weight, Presence of caput and excessive moulding, temperature (Fever), any resuscitation required with oxygen (or) ambu bag, feeding problems were noted. CRP was done of all the new born babies of patients who had PROM. If CRP was positive the babies were started on antibiotics for 7 days and were further screened for blood culture. If blood culture was positive antibiotics were given for 14 days as were the organism detected.

The progress of the babies in the neonatal period was observed for one week for any fever and feeding problems Data regarding each case was made out based on the following proforma.

Maternal and fetal outcome of all the cases were recorded including the follow up of babies up to 7 days. If the neonate was admitted in NICU, complete follow up was done.

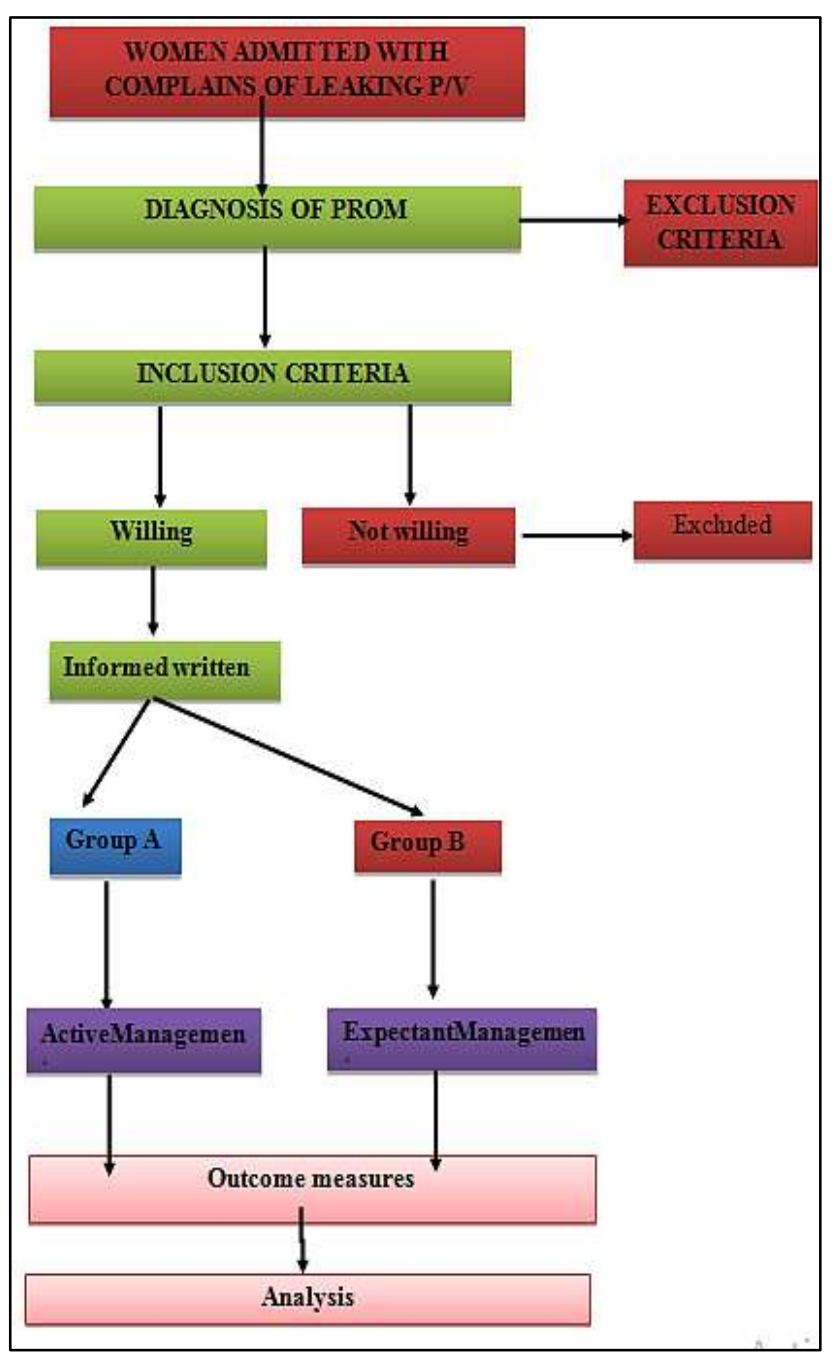

Figure 1: Clinical study process.

\section{RESULTS}

Table 1: Age wise distribution of patients.

\begin{tabular}{|c|c|c|c|}
\hline $\begin{array}{l}\text { Age group } \\
\text { (years) }\end{array}$ & $\begin{array}{l}\text { Active } \\
\text { management }\end{array}$ & $\begin{array}{l}\text { Expectant } \\
\text { management }\end{array}$ & $\$ 2$-value \\
\hline $\begin{array}{l}\text { Up to } 20 \\
\text { years }\end{array}$ & 12 & 16 & \multirow{7}{*}{$\begin{array}{l}3.02 \\
p=0.55 \mathrm{NS}\end{array}$} \\
\hline $21-25$ years & 66 & 61 & \\
\hline $26-30$ years & 19 & 16 & \\
\hline $31-35$ years & 3 & 6 & \\
\hline $36-40$ years & 0 & 1 & \\
\hline Total & 100 & 100 & \\
\hline Mean \pm SD & $23.88 \pm 2.94$ & $24.06 \pm 3.83$ & \\
\hline
\end{tabular}

$66 \%$ of patients in actively managed group were in age range of $21-25$ years and $61 \%$ of expectantly managed group were inn age range of 21-25 years. Mean age of patients of actively managed group was $23.88 \pm 2.94$ and mean age of patients in expectantly managed group was $24.06 \pm 3.83$. By using chi square test no significant difference is found in the ages of patients of both groups $($ Chisquare $=3.02 \mathrm{p}=0.55)$.

Table 2: Parity wise distribution of patients.

\begin{tabular}{|c|c|c|c|}
\hline Parity & $\begin{array}{l}\text { Active } \\
\text { management }\end{array}$ & $\begin{array}{l}\text { Expectant } \\
\text { management }\end{array}$ & $\aleph 2$-value \\
\hline Parity 0 & 70 & 61 & \multirow{5}{*}{$\begin{array}{l}3.94 \\
p=0.267, \mathrm{NS}\end{array}$} \\
\hline Parity 1 & 25 & 27 & \\
\hline Parity 2 & 5 & 11 & \\
\hline Parity 3 & 0 & 1 & \\
\hline Total & 100 & 100 & \\
\hline
\end{tabular}

$70 \%$ of patients of actively managed group and $61 \%$ of expectantly managed group were nulliparous. By using chi square test no significant difference is found in the parity of patients of both the groups chi square $=2.45, \mathrm{p}$ $=0.46$.

Table 3: Distribution of patients according to gestational age.

\begin{tabular}{|c|c|c|c|}
\hline Gestational ag & $\begin{array}{l}\text { Active } \\
\text { management }\end{array}$ & $\begin{array}{l}\text { Expectant } \\
\text { management }\end{array}$ & $\begin{array}{l}\text { s- } \\
\text { value }\end{array}$ \\
\hline 37-38 weeks & 27 & 31 & \multirow{6}{*}{$\begin{array}{l}1.89 \\
\mathrm{p}=0.595 \\
, \mathrm{NS}\end{array}$} \\
\hline $38-39$ weeks & 39 & 36 & \\
\hline $39-40$ weeks & 26 & 29 & \\
\hline$>40.1$ weeks & 8 & 4 & \\
\hline Total & 100 & 100 & \\
\hline Mean \pm SD & $38.61 \pm 0.95$ & $38.53 \pm 0.97$ & \\
\hline
\end{tabular}

$39 \%$ of patients of actively managed and $36 \%$ of expectantly managed group were in gestational age range of 38-39 weeks whereas $8 \%$ of actively managed and $4 \%$ patients of expectantly managed group had gestational age $>40$ weeks by using chi square test there was no significant difference found in the gestational age of both the groups. chi square $=1.89, \mathrm{p}=0.595$. 
Table 4: Distribution of patients according to their PROM to admission interval.

\begin{tabular}{|c|c|c|c|}
\hline PROM & $\begin{array}{l}\text { Active } \\
\text { management }\end{array}$ & $\begin{array}{l}\text { Expectant } \\
\text { management }\end{array}$ & $\begin{array}{l}\aleph 2- \\
\text { value }\end{array}$ \\
\hline$<2$ hours & 19 & 26 & \multirow{8}{*}{$\begin{array}{l}10.43 \\
\mathrm{p}=0.064 \\
, \mathrm{NS}\end{array}$} \\
\hline 2.1- 4 hours & 24 & 29 & \\
\hline 4.1-6 hours & 26 & 31 & \\
\hline $6.1-8$ hours & 18 & 8 & \\
\hline 8.1-10 hours & 6 & 5 & \\
\hline 10.1-12 hours & 7 & 1 & \\
\hline Total & 100 & 100 & \\
\hline Mean \pm SD & $5.39 \pm 3.00$ & $4.42 \pm 2.45$ & \\
\hline
\end{tabular}

$24 \%$ of patients in the actively managed group and $31 \%$ of patients in expectantly managed group had prom to admission interval of 4.1-6 hours whereas 7\% patients of actively managed group and $1 \%$ of patients in expectantly managed group had prom to admission interval of 10.1 12 hours the mean prom to admission interval in actively managed group was $5.39 \pm 3.00$ hours and in expectantly managed group was $4.42 \pm 2.5$ hours. By using chi square test no significant difference is found in the prom to admission interval on patients of both groups.

Table 5: Distribution of patients according to their PROM to delivery interval.

\begin{tabular}{|c|c|c|c|}
\hline PROM & $\begin{array}{l}\text { Active } \\
\text { management }\end{array}$ & $\begin{array}{l}\text { Expectant } \\
\text { management }\end{array}$ & $\begin{array}{l}\aleph 2- \\
\text { value }\end{array}$ \\
\hline$<5$ hours & 4 & 1 & \multirow{7}{*}{$\begin{array}{l}55.73 \\
p=0.0 \\
001, S\end{array}$} \\
\hline 5.1- 10 hours & 27 & 12 & \\
\hline 10.1-15 hours & 46 & 20 & \\
\hline 15.1-20 hours & 23 & 30 & \\
\hline$>20$ hours & 0 & 37 & \\
\hline Total & 100 & 100 & \\
\hline Mean \pm SD & $12.39 \pm 3.88$ & $17.81 \pm 5.25$ & \\
\hline
\end{tabular}

$46 \%$ of patients in the actively managed group and $20 \%$ of patients in expectantly managed group had prom to delivery interval of 10.1-15 hours whereas no patients of actively managed group and $37 \%$ of patients in expectantly managed group had prom to delivery interval of more than 20 hours the mean prom to delivery interval in actively managed group was $12.39 \pm 3.88$ hours and in expectantly managed group was $17.81 \pm 5.25$ hours. By using chi square test significant difference is found in the prom to delivery interval of patients of both groups. As prom to delivery interval was significantly more in expectantly managed group.

Table 6: Distribution of patients according to mode of delivery.

\begin{tabular}{|c|c|c|c|}
\hline $\begin{array}{l}\text { Mode of } \\
\text { delivery }\end{array}$ & $\begin{array}{l}\text { Active } \\
\text { management }\end{array}$ & $\begin{array}{l}\text { Expectant } \\
\text { management }\end{array}$ & $\begin{array}{l}\$ 2- \\
\text { value }\end{array}$ \\
\hline Vaginal & 63 & 71 & \multirow{4}{*}{$\begin{array}{l}1.038 \\
p=0.58 \\
N S\end{array}$} \\
\hline Forceps & 3 & 1 & \\
\hline $\begin{array}{l}\text { Caesarean } \\
\text { Section }\end{array}$ & 34 & 28 & \\
\hline Total & 100 & 100 & \\
\hline
\end{tabular}

$63 \%$ patients of actively managed group and $71 \%$ of expectantly managed group were delivered through vaginal route. Out of 71 patients delivered spontaneously vaginal delivery 30 patients needed augmentation by oxytocin whereas $34 \%$ patients of actively managed group and $28 \%$ of expectantly managed group underwent cesarean. There was no significant difference found in the mode of delivery of both groups on applying chi square.

Table 7: Number of patients who delivered spontaneously in expectant management and need augmentation of labour.

\begin{tabular}{|ll|l|}
\hline $\begin{array}{l}\text { Augmentation } \\
\text { Needed } \\
\text { augmentation }\end{array}$ & 30 & 42.25 \\
\hline $\begin{array}{l}\text { Not needed } \\
\text { augmentation }\end{array}$ & 41 & 57.746 \\
\hline Total & 71 & 100 \\
\hline
\end{tabular}

Table 8: Correlation of mode of delivery with duration of PROM in active management.

\begin{tabular}{|c|c|c|c|c|c|c|}
\hline & & \multicolumn{4}{|c|}{ Duration of leaking PV } & \multirow{2}{*}{ Tota } \\
\hline & & $<6$ hours & 6-12 hours & 12-18 hours & 18-24 hours & \\
\hline \multirow{3}{*}{ Mode of delivery } & Vaginal & 6 & 34 & 22 & 1 & 63 \\
\hline & LSCS & 1 & 15 & 13 & 5 & 34 \\
\hline & Instrumental & 0 & 1 & 2 & 0 & 3 \\
\hline \multicolumn{2}{|l|}{ Total } & 7 & 50 & 37 & 6 & 100 \\
\hline \multicolumn{2}{|l|}{$\aleph 2$-value } & \multicolumn{4}{|c|}{$9.50, p=0.147, \mathrm{NS}$} & \\
\hline
\end{tabular}

Out of 71 patients who underwent spontaneous vaginal delivery 30 patients needed augmentation after getting into active labor. $63 \%$ patients of actively managed group delivered vaginally and 34 patients out of 68 who delivered vaginally had delivered within 12 hours whereas $34 \%$ patients of actively managed group underwent cesarean section and out of those 34 patients 
13 patients had PROM to delivery interval of more than 12 hours and 5 patients had PROM to delivery interval of more than 18 hours. 2 patients out of 3 who underwent instrumental delivery had PROM to delivery interval of more than 12 hours.

Table 9: Correlation of mode of delivery with duration of PROM in expectant management.

\begin{tabular}{|c|c|c|c|c|c|c|c|}
\hline & & \multicolumn{5}{|c|}{ Duration of leaking PV } & \multirow{2}{*}{ Total } \\
\hline & & $<6$ hours & 6-12 hours & 12-18 hours & 18-24 hours & $>24$ hours & \\
\hline \multirow{3}{*}{$\begin{array}{l}\text { Mode of } \\
\text { delivery }\end{array}$} & Vaginal & 0 & 12 & 25 & 33 & 1 & 71 \\
\hline & LSCS & 1 & 3 & 12 & 12 & 0 & 28 \\
\hline & Instrumental & 0 & 0 & 0 & 1 & 0 & 1 \\
\hline
\end{tabular}

$71 \%$ patients of expectantly managed group delivered vaginally and 33 patients out of 71 who delivered vaginally had PROM to delivery time of 18-24 hours and 1 patient had PROM to delivery time more than $24 \mathrm{hrs}$ whereas $28 \%$ (28 out of 100) patients of expectantly managed group underwent cesarean section and out of those 12patients had PROM to delivery interval of 12-18 hours and 12 patients had PROM to delivery interval of 18-24 hours. 1patient who underwent instrumental delivery had PROM to delivery interval of more than 18 hours.

Table 10: Correlation of parity with mode of delivery in active management.

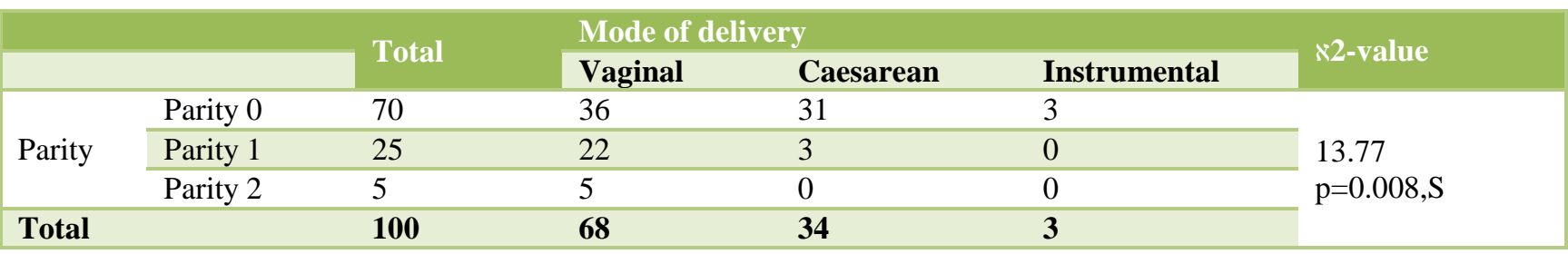

Table 11: Correlation of parity with mode of delivery in expectant management.

\begin{tabular}{|c|c|c|c|c|c|c|}
\hline & & \multirow{2}{*}{ Total } & \multicolumn{3}{|c|}{ Mode of delivery } & \multirow{2}{*}{$\aleph 2$-value } \\
\hline & & & Vaginal & Caesarean & Instrumental & \\
\hline \multirow{4}{*}{ Parity } & Parity 0 & 61 & 36 & 24 & 1 & \multirow{5}{*}{$\begin{array}{l}13.47 \\
p=0.034, S \\
100\end{array}$} \\
\hline & Parity 1 & 27 & 25 & 2 & 0 & \\
\hline & Parity 2 & 11 & 9 & 2 & 0 & \\
\hline & Parity 3 & 1 & 1 & 0 & 0 & \\
\hline Total & & 100 & 71 & 28 & 1 & \\
\hline
\end{tabular}

Table 12: Correlation of parity with PROM to delivery interval in active management.

\begin{tabular}{|c|c|c|c|c|c|c|c|}
\hline & & \multicolumn{4}{|c|}{ PROM to delivery interval } & \multirow{2}{*}{ Total } & \multirow{2}{*}{$\aleph 2$-value } \\
\hline & & $<6$ hours & 6-12 hours & 12-18 hours & 18-24 hours & & \\
\hline \multirow{3}{*}{ Parity } & Para 0 & 2 & 33 & 30 & 5 & 70 & \multirow{4}{*}{$\begin{array}{l}8.70 \\
p=0.191, \mathrm{NS}\end{array}$} \\
\hline & Para 1 & 2 & 18 & 4 & 1 & 25 & \\
\hline & Para 2 & 0 & 2 & 3 & 0 & 5 & \\
\hline Total & & 4 & 53 & 37 & 6 & 100 & \\
\hline
\end{tabular}

$71 \%$ of patients (71 out of 100) in actively managed group had vaginal delivery. Instrumental delivery was noticed in $3 \%$ patients (3 out of 100).
Rate of cesarean and instrumental delivery was more in nulliparous patients $44.2 \%$ (31 out of 70 ) and $4.2 \%$ ( 3 out of 70) as compared to multiparous patients. 
$71 \%$ of patients (71 out of 100) in expectantly managed group had vaginal delivery out of which 36 were nulliparous. Instrumental delivery was noticed in $1 \%$ patients (1 out of 100).

Rate of cesarean and instrumental delivery was more in nulliparous patients $39.34 \%$ (24 out of 61 ) and $1.6 \%$ (1 out of 61) as compared to multiparous patients.
In actively managed group in actively managed group there were 70 nulliparaous patients of which 30 patients had PROM to delivery interval $>12$ hours and 5 patients had PROM to delivery interval $>18$ hours. In multiparous patients PROM to delivery interval was short only 4 patients with parity 1 had PROM to delivery interval $>12$ hours and only 3 patients with parity more than 1 had PROM to delivery interval of $>12$ hours.

Table 13: Correlation of parity with PROM to delivery interval in expectant management.

\begin{tabular}{|c|c|c|c|c|c|c|c|c|}
\hline & & \multicolumn{5}{|c|}{ PROM to delivery interval } & \multirow[b]{2}{*}{ Total } & \multirow{2}{*}{$\aleph 2$-value } \\
\hline & & $<6$ hours & 6-12 hours & 12-18 hours & 18-24 hours & $>24$ hours & & \\
\hline \multirow{4}{*}{ Parity } & Para 0 & 0 & 4 & 27 & 29 & 1 & 61 & \multirow{5}{*}{$\begin{array}{l}20.86 \\
p=0.042, S\end{array}$} \\
\hline & Para 1 & 0 & 7 & 8 & 12 & 0 & 27 & \\
\hline & Para 2 & 1 & 4 & 2 & 4 & 0 & 11 & \\
\hline & Para 3 & 0 & 0 & 0 & 1 & 0 & 1 & \\
\hline Total & & 1 & 15 & 37 & 46 & 1 & 100 & \\
\hline
\end{tabular}

In expectantly managed group there were 61 nulliparaous patients of which 27 patients had PROM to delivery interval $>12$ hours and 29 patients had PROM to delivery interval $>18$ hours. In multiparous patients PROM to delivery interval was short only 7 patients with parity $>1$ and 4 patients with parity $>2$ had PROM to delivery interval $>6$ hours and 12 patients with parity more than $>1$ had PROM to delivery interval of $>18$ hours. Progress of labor speeded among women with higher parity and gravidity.

Table 14: Distribution of patients according indications of caesarean section.

\begin{tabular}{|lllll|}
\hline Indications & Active management & Expectant management & \$2-value & p-value \\
\hline Fetal distress & 17 & 20 & 0.733 & 0.39, NS \\
\hline Prolonged $2^{\text {nd }}$ stage & 5 & 7 & 0.69 & 0.40, NS \\
\hline Cervical dystocia & 0 & 1 & 1.00 & $0.31, \mathrm{NS}$ \\
\hline Non progress of labour & 10 & 0 & 10.53 & $0.0001, \mathrm{~S}$ \\
\hline Failure of induction & 2 & 0 & 2.02 & $0.15, \mathrm{NS}$ \\
\hline Total & $\mathbf{3 4}$ & $\mathbf{2 8}$ & & \\
\hline
\end{tabular}

Table 15: Distribution of patients according to Apgar score at 1 minute.

\begin{tabular}{|llll|}
\hline Apgar score at 1 min & Active management & Expectant management & s2-value \\
\hline$<7$ & 10 & 11 & 0.05 \\
\hline$\geq 7$ & 90 & 89 & $\mathrm{p}=0.81, \mathrm{NS}$ \\
\hline Total & $\mathbf{1 0 0}$ & $\mathbf{1 0 0}$ & \\
\hline
\end{tabular}

10 babies out of 100 of actively managed patients had.

In actively managed group 17 (out of 34) patients underwent cesarean in view of fetal distress whereas in expectantly managed group 20 (out of 28) patients underwent cesarean in view of fetal distress. On applying chi square test this was non-significant as $p$ value is $0.39<0.05$.
In actively managed group 10 (out of 34) patients underwent cesarean in view of non-progress of labor whereas in expectantly managed group 0 (out of 28) /no patients underwent cesarean in view of non-progress of labor. On applying chi square test this was significant as $\mathrm{p}$ value is $0.0001<0.05$. 
Thus, fetal distress was the most common indication for cesarean section in both the groups. Apgar $<7$ at 1 minute of birth whereas 11 babies out of 100 of expectantly managed patients had Apgar <7 at 1 minute of birth. On applying chi square test there was no significant difference found in Apgar score at 1 minute of birth of babies in both the groups.

Table 16: Distribution of patients according to Apgar score at 5 minutes.

\begin{tabular}{|c|c|c|c|}
\hline $\begin{array}{l}\text { Apgar } \\
\text { score } \\
\text { at } 5 \text { min }\end{array}$ & $\begin{array}{l}\text { Active } \\
\text { management }\end{array}$ & $\begin{array}{l}\text { Expectant } \\
\text { management }\end{array}$ & $\$ 2$-value \\
\hline$<7$ & 2 & 1 & \multirow{3}{*}{$\begin{array}{l}0.33 \\
p=0.56, N S\end{array}$} \\
\hline$\geq 7$ & 98 & 99 & \\
\hline Total & 100 & 100 & \\
\hline
\end{tabular}

2 babies out of 100 of actively managed patients had.

Apgar $<7$ at 5 minute of birth whereas 1 babies out of 100 of expectantly managed patients had Apgar $<7$ at 5 minute of birth. On applying chi square test there was no significant difference found in Apgar score at 5 minute of birth of babies in both the groups.

In the present study in actively managed group $6 \%$ neonates had meconium stained liqor at birth $10 \%$ neonates had birth asphyxia and $6 \%$ neonates had hyperbilirubinemia and in expectantly managed group 4 $\%$ neonates meconium stained liqor at birth, $11 \%$ neonates had birth asphyxia and $1 \%$ neonates had hyperbilirubinemia

On applying chi square there was no significant difference in neonatal outcome at birth in both the groups.

In actively managed group $15 \%$ babies had NICU admission whereas in expectantly managed group $11 \%$ babies had NICU admission. On applying Chi square test there was no significant difference found in the NICU admission of both the groups.

Table 17: Distribution of patients according to neonatal outcomes.

\begin{tabular}{|llll|}
\hline Neonatal outcome & Active management & Expectant management & $\$ 2$-value \\
\hline Meconium & 6 & 4 & $0.42, \mathrm{p}=0.51, \mathrm{NS}$ \\
\hline Birth asphyxia & 10 & 11 & $0.05, \mathrm{p}=0.81, \mathrm{NS}$ \\
\hline hyperbilirubinemia & 6 & 1 & $3.70, \mathrm{p}=0.05, \mathrm{NS}$ \\
\hline Healthybaby & 78 & 84 & \\
\hline Total & $\mathbf{1 0 0}$ & $\mathbf{1 0 0}$ & \\
\hline
\end{tabular}

Table 18: Distribution of patients according to NICU stay.

\begin{tabular}{|llll|}
\hline NICU Stay & Active management & Expectant management & \$2-value \\
\hline Present & 15 & 11 & 0.70 \\
\hline Absent & 85 & 89 & $\mathrm{p}=0.40, \mathrm{NS}$ \\
\hline Total & $\mathbf{1 0 0}$ & $\mathbf{1 0 0}$ & \\
\hline
\end{tabular}

Table 19: Distribution of patients according to CRP.

\begin{tabular}{|lllll|}
\hline Neonatal morbidity & Active management & Expectant management & *2-value & p-value \\
\hline CRP Positive & 6 & 10 & 1.08 & 0.29 \\
\hline Blood culture positive & 2 & 4 & 0.68 & 0.40 \\
\hline CRP Negative & 94 & 90 & 1.08 & 0.29 \\
\hline Total & $\mathbf{1 0 0}$ & $\mathbf{1 0 0}$ & & \\
\hline
\end{tabular}

In the present study in actively managed group 6 out of $100(6 \%)$ neonates were CRP positive whereas blood culture was positive for $2 \%$ neonates. In expectant group 10 out $100(10 \%)$ neonates had CRP positive, and blood culture was positive for $4 \%$. All neonates who had CRP positive were started on antibiotics for 7 days and those who had blood culture positive were given antibiotics for 14 days as per the culture sensitivity. On applying chi square test there was no significant difference among two groups.

In actively managed group 12 patients out of 100 had febrile episodes 3 patients had PPH and 1 patient had wound discharge whereas in expectantly managed group 8 patients out of 100 had febrile episodes 7 patients had $\mathrm{PPH}$ and no patient had wound discharge . on applying chi square test no significant difference was found in both the groups. 
Table 20: Comparison of maternal morbidity.

\begin{tabular}{|llll|}
\hline Maternal morbidity & Active management & Expectant management & \&2-value \\
\hline Fever & 12 & 18 & $1.41, \mathrm{p}=0.23, \mathrm{NS}$ \\
\hline PPH & 3 & 7 & $1.68, \mathrm{p}=0.19, \mathrm{NS}$ \\
\hline Wound Discharge & 1 & 3 & $1.02, \mathrm{p}=0.31, \mathrm{NS}$ \\
\hline Nil & 84 & 72 & \\
\hline Total & $\mathbf{1 0 0}$ & $\mathbf{1 0 0}$ & \\
\hline
\end{tabular}

Table 21: Distribution of patients according to hospital stay.

\begin{tabular}{|c|c|c|c|}
\hline Hospital stay & Active management & Expectant management & $\aleph 2$-value \\
\hline Up to 5 days & 37 & 0 & \multirow{6}{*}{$\begin{array}{l}51.91 \\
\mathrm{p}=0.0001, \mathrm{~S}\end{array}$} \\
\hline 5-8 days & 48 & 66 & \\
\hline 8-10 days & 15 & 24 & \\
\hline$>10$ days & 0 & 10 & \\
\hline Total & 100 & 100 & \\
\hline Mean \pm SD & $6.56 \pm 1.58$ & $8.34 \pm 1.47$ & \\
\hline
\end{tabular}

$48 \%$ patients (48 out of 100) of actively managed group had hospital stay of 5-8 days and $66 \%$ patients (47 out of $100)$ of expectantly managed group had hospital stay of 5-8 days. On applying chi square test significant difference was found in hospital stay of both the groups (chi square $51.91 \mathrm{p}=0.0001$, s). Hospital stay was significantly prolonged in expectantly managed patients.

Statistical analysis was done by using descriptive and inferential statistics using chisquare test and software used in the analysis were SPSS 17.0 version and GraphPad Prism 5.0 version and $\mathrm{p}<0.05$ is considered as level of significance.

\section{DISCUSSION}

During the study period of 24 months there were 6433 obstetric confinements. 5965 deliveries. Out of which, 680 women came with complain of leaking per vaginum and $477(7.99 \%)$ were diagnosed to have prelabour rupture of membranes (PLROM).There were 125.928 (26.4\%) women who had prelabour rupture of membranes before 37 weeks of gestation and were excluded and $352(73.6 \%)$ had PLROM after 37 weeks of gestation. Those women who were less than 37 weeks of gestation and more than 41 weeks of gestation and the women with other obstetric complications LIKE

- $\quad$ PROM more than 12 hours

- Patients with features of chorioamnionitis like fever, tachycardia, uterine tenderness and foul smelling liquor

- Fetal distress and meconium stained amniotic fluid at admission

- Active labour at admission and cervical dilatation more than $4 \mathrm{~cm}$ (who criteria of active labor

- Previous caesarian section

- History of ante partum hemorrhage
- Maternal medical diseases like severe pre ecclampsia, diabetes or heart diseases

- IUGR and fetal anomalies

- Abnormal presentation and multiple fetus were excluded.

Total study subjects were 200 women, who were randomized in two groups,

\section{Group A and Group E}

100 patients of group a were actively managed and 100 patients of group were expectantly managed.

The incidence of PROM in the present study was $7.99 \%$ in our hospital during the study period which is comparable with study done by Vaishnav et al where PROM incidence was $8.09 \%$ and with study done by Kiranmaie $\mathrm{S}$ in which PROM incidence was found to be $9.8 \%$.

\section{Distribution of patients according to age}

In the present the mean age of patients in both the groups i.e. actively manage was $23.88 \pm 2.94$ years and in expectantly managed group was $24.06 \pm 3.83$ years which was comparable to Snehamay C et al study where mean

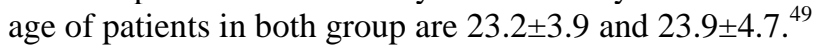

In the study done by Krupa $\mathrm{G}$ et al where mean age in actively managed group was $23.6 \pm 6.1$ years and in expectantly managed group was $23.7 \pm 6.2$ years. $^{38}$ In study done by Yaqub $U$ et al the mean age in actively managed group was $26.53 \pm 3.576$ years and in expectantly managed group was $26 \pm 3.606$ years. ${ }^{50}$ 
Table 22: Distribution of patients according to age.

\begin{tabular}{|llll|}
\hline Study & Active & Expectant & $\begin{array}{l}\text { P } \\
\text { value }\end{array}$ \\
\hline Present study & $23.88 \pm 2.94$ & $24.06 \pm 3.83$ & NS \\
\hline Snehamay C et al & $23.2 \pm 3.9$ & $23.9 \pm 4.7$ & NS \\
\hline Krupa G et al & $23.6 \pm 6.1$ & $23.7 \pm 6.2$ & NS \\
\hline Yaqub U et al & $26.53 \pm 3.576$ & $26 \pm 3.606$ & NS \\
\hline
\end{tabular}

Table 2 distribution of patients according to antenatal/prenatal care.

In the present study (80\%) 80 out of 100 patients of actively managed group were booked and (20\%) 20 out of 100 patients were unbooked whereas in expectantly managed group (82\%) 82 out of 100 patients were booked and (18\%)18 out of 100 patients were unbooked.

Whereas in study done by Vaishnav et al $27.27 \%$ patients were booked in actively managed group and $72.72 \%$ were unbooked and in expectantly managed group total booked patients were $33.33 \%$ and $66.66 \%$ patients were unbooked.

\section{Distribution of patients according to parity}

In the present study in actively managed group $70 \%$ (70 out of 100) were nulliparous/primipara and 30 patients were multiparous and in expectantly managed group $61 \%$ (61 out of 100) patients were nulliparous/primipara and $39 \%$ (39 out of 100) were multiparous.

Out of 200 patients of prelabor rupture of membranes total number of nulliparous / primiparou s patients were $131(65.5 \%)$ which is similar to study done by Chaudhuri Snehamay et al where out of 223 patients include 168 $(75.33 \%)$ were nulliparous. In study done by Vaishnav et al there were $59.09 \%$ (39 out of 66) nullipara/ multigravida patients. ${ }^{49}$

\section{Distribution of patients according to gestational age}

In the present study the mean gestational age in the actively managed group was $38.61 \pm 0.95$ and in expectantly managed group was $38.53 \pm 0.97$. In the study done by Chaudhari $\mathrm{S}$ et al the mean gestational age in actively managed was $38.7 \pm 1.3$ and expectantly managed group $38.0 \pm 1.1$ and in study done by Yaqub $U$ et al the mean age in actively managed group was $38.6 \pm 1.054$ and in expectantly managed group was $38.60 \pm 0.909$. $^{49,50}$

\section{Thus the present study was comparable to above studies}

Distribution of patients according to their PROM to admission interval. In the study done by Gracakrupa et al the mean PROM, to delivery interval was $3.1 \pm 2.3$ hours in actively managed group and $2.9 \pm 2.2$ in expectanly managed group. ${ }^{38}$
In the present study the mean PROM to admission interval was $5.39 \pm 3.00$ hours in actively managed group and $4.42 \pm 2.45$ hours in expectantly managed group.

Table 23: Distribution of patients according to PROM to delivery interval.

\begin{tabular}{|llll|}
\hline Study & \multicolumn{2}{l}{ Prom to delivery interval } & \\
& Active & Expectantly & P value \\
\hline $\begin{array}{l}\text { Gracakrupa et } \\
\mathrm{al}^{38}\end{array}$ & $18.9 \pm 11.0$ & $27.5 \pm 14.8$ & $<0.0001$ \\
\hline Umairah et al $^{50}$ & $17.4 \pm 2.0$ & $22.2 \pm 2.0$ & $<0.0001$ \\
\hline $\begin{array}{l}\text { Chaudhuri S et } \\
\mathrm{al}^{49}\end{array}$ & $17.10 \pm 10.3$ & $21.63 \pm 10.3$ & $<0.001$ \\
\hline Shanthi et al $^{38}$ & $11.46 \pm 6.01$ & $30.49 \pm 16.07$ & \\
\hline Present study & $12.39 \pm 3.88$ & $13.71 \pm 5.34$ & $<0.003$ \\
\hline $\begin{array}{l}\text { Vaishanav et } \\
\text { al }^{44}\end{array}$ & 11.67 hours & 8.05 & \\
\hline
\end{tabular}

In the present study as well as in above given study PROM to delivery interval was significantly higher in expectantly managed group.

Table 24: Comparison of occurrence of spontaneous delivery.

\begin{tabular}{|c|c|c|c|}
\hline Study & Active & Expectant & P value \\
\hline Present study & $63 \%$ & $71 \%$ & $0.58 \mathrm{NS}$ \\
\hline Gracakrupa et $\mathrm{al}^{38}$ & $80 \%$ & $69 \%$ & \\
\hline Umairah et $\mathrm{al}^{50}$ & $83.8 \%$ & $76.0 \%$ & NS \\
\hline Chaudhuri $\mathrm{S}$ et $\mathrm{al}^{49}$ & $78.5 \%$ & $57.14 \%$ & \\
\hline Drshanthi et $\mathrm{al}^{42}$ & $70.1 \%$ & $88.6 \%$ & \\
\hline Vaishanav et al ${ }^{44}$ & 78.785 & $74 \%$ & NS \\
\hline
\end{tabular}

In the present study the percentage of spontaneous vaginal delivery was $63 \%$ in actively managed and $71 \%$ in expectantly managed group, thus no significant difference was found in the two groups. Whereas in the studies done by Chaudhuri S et al and Gracakrupa et al the percentage of spontaneous vaginal delivery was significantly more in actively managed group as compared to expectantly managed group..$^{39,49}$

In study done by Shanthi et al $70.1 \%$ patients had spontaneous vaginal delivery in actively managed group and $88.6 \%$ patients had spontaneous vaginal delivery in expectantly managed group. ${ }^{42}$

In the present study in expectantly managed group out of 71 spontaneous vaginal delivery $30 \quad(42.25 \%$ of spontaneous vaginal delivery) needed augmentation of labor after patient was in active labor which was comparable to study done by Shanthi et al where in expectantly managed group $67.8 \%$ of all spontaneous vaginal delivery needed augmentation of labor. ${ }^{42}$ 
Table 25: Comparison of rate of caesarean section.

\begin{tabular}{|c|c|c|}
\hline Study & Active & Expectant \\
\hline Present study & $34 \%$ & $28 \%$ \\
\hline Drshanthi et al $^{42}$ & $5.7 \%$ & $12 \%$ \\
\hline Graca krupa et $\mathrm{al}^{38}$ & $15 \%$ & $23 \%$ \\
\hline Umairah et al $^{50}$ & $31 \%$ & $56 \%$ \\
\hline Chaudhuri $\mathrm{S}$ et al ${ }^{49}$ & $15 \%$ & $24 \%$ \\
\hline
\end{tabular}

The rate of caesarean in the present study was $34 \%$ in actively managed patients and $28 \%$ in expectantly managed patient. Though the rate is slightly higher in actively managed group but. there is no significant difference in view of caesarean section rate in both the groups. The study is comparable to all the above given study.

But in studies done by Shathi et al, Gracakrupa et al, Umairah et al, Chaudhuri $\mathrm{S}$ et al the rate of caesarean section was significantly higher in expectantly managed patient. ${ }^{38,42,49}$ Whereas in study done by Zamzami the rate of caesarean section was twice in actively managed group than in expectant group. ${ }^{4}$

In study done by Pintucciet al the rate of caesarean was significantly lower in expectant group as compared to active group. Odd Ratio $=1.76 ; 95 \%$ confidence interval 1.03-3.02; $\mathrm{P}<0.004){ }^{47}$

Table 10 and 11 in this study there was no significant correlation found in mode of delivery with duration of PROM in both the expectant and actively managed group which was similar to the study done by Vaishanav et al. ${ }^{44}$

In table 12 and 13 there was significant correlation was found between parity and mode of delivery in both active and expectantly managed group i.e rate of cesarean was high in primi /nulliparawomen and was significantly low in multiparous women when compared. But in the study done by Vaishanavet al44 (2012) there was no correlation found in the parity and mode of delivery.

In table 19 in actively managed group PROM to delivery interval was less in multiparaous patients but no significant correlation was found.

But in table 20 significant correlations was found in PROM to delivery interval and parity of the patient. The interval decreased with multiple gestations. Progress of labor was speeded among women with higher parity and gravidity.

In table 20 distributions of patients according to indication of caesarean section. In the present study $72.72 \%$ (24 of 33 ) patients underwent caesarean section with indication of fetal distress/ non assuring ctg in expectant group whereas in active group only $41.37 \%$ (12 out of 29) of underwent caesarean section with the indication of fetal distress .Fetal distress was the most common indication of caesarean in both the groups.

Table 26: Comparison on basis of Apgar score $<7$ at 1 minute of birth.

\begin{tabular}{|c|c|c|c|}
\hline & Active & Expectant & P value \\
\hline Present study & $10 \%$ & $11 \%$ & $0.81 \mathrm{NS}$ \\
\hline Drshanthi et $\mathrm{al}^{42}$ & $14 \%$ & $18.9 \%$ & NS \\
\hline Gracakrupa et $\mathrm{al}^{38}$ & $5.3 \%$ & $8 \%$ & $0.87 \mathrm{NS}$ \\
\hline${\text { Umairah et } \mathrm{al}^{50}}^{50}$ & $7.29 \%$ & $9.90 \%$ & $0.363 \mathrm{NS}$ \\
\hline Chaudhuri $\mathrm{S}$ et $\mathrm{al}^{49}$ & $5.4 \%$ & $7.1 \%$ & $0.59 \mathrm{NS}$ \\
\hline
\end{tabular}

In the present study in active management group only 10 $\%$ neonates had APGAR $<7$ at 1 minute of birth whereas in expectant managed group $11 \%$ neonates had APGAR $<7$ at 1 minute of birth. On application of Chi square there was no significant difference found in both the group.

Thus the present study is comparable to above given study.

Table 27: Comparison on basis of Apgar score at 5 minutes of birth.

\begin{tabular}{|llll|}
\hline & Active & Expectant & P value \\
\hline Present study & $2 \%$ & $1 \%$ & $0.56 \mathrm{NS}$ \\
\hline Umairah et al $^{50}$ & $7.29 \%$ & $9.90 \%$ & $0.363 \mathrm{NS}$ \\
\hline Chaudhuri S et al & $5.4 \%$ & $7.1 \%$ & $0.59 \mathrm{NS}$ \\
\hline
\end{tabular}

In the present study only $2 \%$ neonates had apgar $<7$ after 5 minutes of birth in active group whereas only $1 \%$ in expectant managed group. There was no significant difference found pn applying Chi square.

Thus, the present study is comparable to studies done by Umairahet al and ChaudhuriS et al. ${ }^{49,50}$

Table 28: Comparison on basis of NICU admission of neonates.

\begin{tabular}{|llll|}
\hline & Active & Expectant & P value \\
\hline Present study & $15 \%$ & $11 \%$ & 0.40 \\
\hline Chaudhuri S et al $^{49}$ & $2.7 \%$ & $3.5 \%$ & 0.71 \\
\hline Vaishanav et al $^{38}$ & $1.5 \%$ & $1.5 \%$ & $0 \mathrm{NS}$ \\
\hline
\end{tabular}

In the present study total NICU admissions were $15 \%$ in active group and 11 in expectant group. On applying chi square no significant difference was found among both the groups.

Thus, the study is comparable to similar study done by Chaudhuri $\mathrm{S}$ et al and Vaishanav et al. ${ }^{38,49}$

\section{Comparison on basis neonatal outcome at birth}

In the present study in actively managed group $6 \%$ neonates had meconium stained liqor at birth $10 \%$ 
neonates had birth asphyxia and 6\% neonates had hyperbilirubinemia and in expectantly managed group $4 \%$ neonates meconium stained liqor at birth, $11 \%$ neonates had birth asphyxia and $1 \%$ neonates had hyperbilirubinemia. On applying chi square there was no significant difference in neonatal outcome at birth in both the groups

In study done by Chaudhari $\mathrm{S}$ in actively managed group $5.4 \%$ neonates had birth asphyxia at birth and needed resuscitation with oxygen $3 \%$ neonates had feeding problems. $^{49}$

Whereas in expectant group $4.4 \%$ neonates had birth asphyxia and needed resuscitation with oxygen $3.5 \%$ neonates needed ventilation after initial resuscitation and $3.5 \%$ neonates had feeding problems.

In the study done by Shanthi et al in actively managed group $7.5 \%$ neonates had meconium stained liqor at birth $9.4 \%$ neonates had birth asphyxia and needed resuscitation, $1.8 \%$ neonates had feeding problems whereas in expectantly managed group $8 \%$ neonates had meconium stained liqor at birth $6 \%$ neonates had birth asphyxia and needed resuscitation, $2 \%$ neonates had feeding problems. ${ }^{38}$

Thus the present study is comparable to the above studies.

\section{Comparison on basis of neonatal CRP and infection}

In the present study in actively managed group 6 out of $100(6 \%)$ neonates were CRP positive whereas blood culture was positive for $2 \%$ neonates. In expectant group 11 out 100(11\%) neonates had CRP positive, and blood culture was positive for $4 \%$. All neonates who had CRP positive were started on antibiotics for 7 days and those who had blood culture positive were given antibiotics for 14 days as per the culture sensitivity. On applying chi square test there was no significant difference among two groups.

In study done by Vaishanav et al in active managed group 13.63 neonates had CRP positive and $4.5 \%$ neonates had blood culture positive whereas in expectant group 16.66 neonates had CRP positive and $4.5 \%$ neonates had blood culture positive. $^{38}$

In the study done by Chaudhuri $\mathrm{S}$ et al $2.7 \%$ neonates in actively managed group and $3.5 \%$ neonates in expectant group were screened positive for infection. ${ }^{49}$

In the study done by Umairah et al $4.69 \%$ neonates in actively managed group and $6.25 \%$ in expectant group were screened positive for neonatal sepsis. ${ }^{50}$ Though, on applying chi square test no significant difference was found in both the groups.

Thus, the present study is comparable to above studies

\section{Comparison on basis of maternal morbidity}

In the present study in actively managed group $12 \%$ patients had febrile episodes, $3 \%$ patients had postpartum hemorrhage and $1 \%$ patient had wound discharge whereas in expectantly managed group $18 \%$ patients had febrile episode, 7 patients had post-partum haemorrhage and 3 patients had wound discharge. On applying Chi square test no significant difference was found among the both groups.

Whereas in the study done by Chaudhuri $\mathrm{S}$ et al in actively managed group $1.8 \%$ patients had febrile episodes whereas in expectant group $0.8 \%$ had febrile episodes. $^{49}$ There was no significant difference found in terms of maternal morbidity among both the groups.

In the study done by DrShanthi et al42 (2008) $3.81 \%$ maternal morbidity in actively managed group and $4 \%$ maternal morbidity in expectantly managed group. There was no significant difference found in terms of maternal morbidity among both the groups.

In the study done by Vaishanav et al 38(2012) in actively managed group $3 \%$ patients had febrile episodes and $1.5 \%$ patients had wound gap whereas in expectantly managed group $7.5 \%$ patients had febrile episodes and $4.5 \%$ patients had wound gap . There was no significant difference found in terms of maternal morbidity among both the groups.

Thus, the present study is comparable to the above studies.

Table 29: Comparison on basis of mean hospital stay.

\begin{tabular}{|lll|l|}
\hline & Active & Expectant & $\begin{array}{l}\text { P } \\
\text { value }\end{array}$ \\
\hline Present study & $6.56 \pm 1.58$ & $8.34 \pm 1.47$ & $\begin{array}{l}0.0001 \\
\text { S }\end{array}$ \\
\hline $\begin{array}{l}\text { Vaishanav et } \\
\text { al }^{38}\end{array}$ & 6.87 & 5.12 & \\
\hline Shanthi et al $^{42}$ & $3.66 \pm 1.27$ & $2.76 \pm 1.73$ & $0.001 \mathrm{~S}$ \\
\hline
\end{tabular}

In the present study in actively managed group mean hospital stay was $6.56 \pm 1.27$ days and in expectant group $8.34 \pm 1.47$ days. Mean hospital was significantly more in expectant group as compared to actively managed group. The present study was comparable to the above studies.

Limitations of this study were the long term follow up of mothers and neonates who were admitted to NICU or were treated for infection could not be taken.

Due to increased awareness of fetal and maternal outcome it was difficult to counsel patient for expectant management. 
In expectant group few patients had fever more than 100 ' $\mathrm{F}$ during the management and thus had to be managed actively and had to be excluded from the study.

Mean hospital stay of patients in expectantly managed group was significantly more in active managed group thus adding to increased hospital charges.

\section{CONCLUSION}

There were no statistically significant difference in the rates of neonatal and maternal infections and caesarean section in both the actively managed and expectantly managed groups.

In the present study in expectant group $71 \%$ patients went into active labor spontaneously but out of that $42.254 \%$ patients needed augmentation of labor with oxytocin drip. The patients in expectant management group were in labor for many hours thus increasing the anxiety of mother and clinician.

There was significant correlation found in the parity and pre labor rupture of membranes to delivery interval as the duration was short in multiparous patients as compared to nulliparous patients. Progress of labor was speeded among women with higher parity.

There was significant correlation was found between parity and mode of delivery in both active and expectantly managed group i.e rate of caesarean was high in primi /nullipara women $(44.28 \%$ ) and the rate was significantly low in multiparous women (10\%) when compared in both the actively managed and expectantly managed groups.

Immediate labor induction in cases of term pre labor rupture of membranes has a similar performance to that of expectant management for 12-18 hours with respect to maternal and perinatal outcomes.

However, active management is responsible for shortening the latency period, the total time between prelabor rupture of membranes and delivery and total maternal hospital stay.

Funding: No funding sources

Conflict of interest: None declared

Ethical approval: The study was approved by the Institutional Ethics Committee

\section{REFERENCES}

1. Larrañaga-Azcárate C, Campo-Molina G, PérezRodríguez AF, Ezcurdia-Gurpegui M. Dinoprostone vaginal slow-release system (Propess) compared to expectant management in the active treatment of premature rupture of the membranes at term: impact on maternal and fetal outcomes. Acta Obstet Gynecol Scand. 2008;87(2):195-200.
2. Gunn GC, Mishell DR, Morton DG. Premature rupture of the fetal membranes. A review. Am J Obstet Gynecol. 1970;106(3):469-83.

3. Zamzami TYY. Prelabor rupture of membranes at term in low-risk women: induce or wait? Arch Gynecol Obstet. 2006;273(5):278-82.

4. Hannah ME, Ohlsson A, Farine D, Hewson SA, Hodnett ED, Myhr TL, et al. Induction of labor compared with expectant management for prelabor rupture of the membranes at term. Termprom Study Group. N Engl J Med. 1996;334(16):1005-10.

5. Ozden S, Delikara MN, Avci A, Fiçicioglu C. Intravaginal misoprostol vs expectant management in premature rupture of membranes with low Bishop scores at term. Int J Gynaecol Obstet Off Organ Int Fed Gynaecol Obstet. 2002;77(2):109-15.

6. Flenady V, King J. Antibiotics for prelabour rupture of membranes at or near term. Cochrane Database Syst Rev. 2002;(3):CD001807.

7. Kodkany BS, Telang MA. Premature rupture of membranes. A study of 100 cases. J Obstet Gynaecol India. 2002;41(4).

8. Allen SR. Tocolytic therapy in preterm PROM. Clin Obstet Gynecol. 1998;41(4):842-8.

9. Mercer BM. Preterm premature rupture of the membranes. Obstet Gynecol. 2003;101(1):178-93.

10. Moberg LJ, Garite TJ, Freeman RK. Fetal heart rate patterns and fetal distress in patients with preterm premature rupture of membranes. Obstet Gynecol. 1984;64(1):60-4.

11. Jones G. Pre labour rupture of the membrane. In: Arnold Mothhg, editor. Obstetrics and GynaecologyAn evidenced based text for MRCOG: Oxford University press; 2004:297.

12. Obi SN, Ozumba BC. Pre-term premature rupture of fetal membranes: the dilemma of management in a developing nation. J Obstetr Gynaecol. 2007;27(1):37-40.

13. Liu J, Feng $\mathrm{ZC}$, Wu J. The incidence rate of premature rupture of membranes and its influence on fetal-neonatal health: a report from Mainland China. J Trop Pediatr. 2009:051.

14. Knox IC, Hoerner JK. The role of infection in premature rupture of the membranes. Amer J Obstetr Gynecol. 1950;59(1):190-4.

15. Benirschke K. A review of the pathologic anatomy of the human placenta. American journal of obstetrics and gynecology. 1962;84(11):1595-622.

16. Polishuk WZ, Palti Z, Rabau E, Lunenfeld B, David A. Pregnancy in a case of Sheehan's syndrome following treatment with human gonadotrophins. BJOG: An Internat J Obstetr Gynaecol. 1965;72(5):778-80.

17. Lavery JP, Miller CE. Deformation and creep in the human chorioamniotic sac. Amer J Obstetr Gynecol. 1979;134(4):366-75.

18. Al-Zaid NS, Bou-Resli MN, Goldspink G. Bursting pressure and collagen content of fetal membranes and their relation to premature rupture of the 
membranes. BJOG: An Intern J Obstetr Gynaecol. 1980;87(3):227-9.

19. Dale PO, Tanbo T, Bendvold E, Moe N. Duration of the latency period in preterm premature rupture of the membranes. Maternal and neonatal consequences of expectant management. Europ J Obstetr Gynecol Repro Bio. 1989;30(3):257-62.

20. Vadillo-Ortega FE, González-Avila GE, Karchmer S, Cruz NM, Ala-Ruiz AA, Lama MS. Collagen metabolism in premature rupture of amniotic membranes. Obstetr and Gynecol. 1990;75(1):84-8.

21. Malak TM, Bell SC. Structural characteristics of term human fetal membranes: a novel zone of extreme morphological alteration within the rupture site. BJOG: An Intern J Obstetr Gynaecol. 1994;101(5):375-86.

22. Parry S, Strauss JF. Premature rupture of the fetal membranes. New Eng J Med. 1998;338(10):663-70.

23. Gosselink CA, Ekwo EE, Woolson RF, Moawad A, Long CR. Dietary habits, pre-pregnancy weight, and weight gain during pregnancy: Risk of preterm rupture of amniotic sac membranes. Acta Obstet Gynecol Scandinavica. 1992;71(6):425-38.

24. Ekwo EE, Gosselink CA, Moawad A. Previous pregnancy outcomes and subsequent risk of preterm rupture of amniotic sac membranes. BJOG: An Intern J Obstetr Gynaecol. 1993;100(6):536-41.

25. Abe $T$. The detection of the rupture of fetal membranes with the nitrazine indicator. An Intern J Obstetr Gynaecol. 1940;39(3):400-4.

26. Zondek B, Rozin S. Cervical Mucus Arborization: Its use in the determination of corpus luteum function. $\mathrm{J}$ Obstetr Gynaecol. 1954;3(5):463-70.

27. Borten M, Friedman EA. Amniotic fluid ferning in early gestation. An Intern J Obstetr Gynaecol. 1986;154(3):628-30.

28. Kappy KA, Cetrulo CL, Knuppel RA, Ingardia CJ, Sbarra AJ, Scerbo JC, et al. Premature rupture of the membranes: a conservative approach. Am J Obstet Gynecol. 1979;134(6):655-61.

29. Kappy KA, Cetrulo CL, Knuppel RA, Ingardia CJ, Sbarra AJ, Scerbo JC, et al. Premature rupture of the membranes at term. A comparison of induced and spontaneous labors. J Reprod Med. 1982;27(1):2933.

30. Alcalay M, Hourvitz A, Reichman B, Luski A, Quint J, Barkai G, et al. Prelabour rupture of membranes at term: early induction of labour versus expectant management. Eur J Obstet Gynecol Reprod Biol. 1996;70(2):129-33.

31. Shalev E, Peleg D, Eliyahu S, Nahum Z. Comparison of 12- and 72-hour expectant management of premature rupture of membranes in term pregnancies. Obstet Gynecol. 1995;85(5 Pt 1):766-8.

32. Hjertberg R, Hammarström M, Moberger B, Nordlander E, Granström L. Premature rupture of the membranes (PROM) at term in nulliparous women with a ripe cervix. A randomized trial of 12 or 24 hours of expectant management. Acta Obstet Gynecol Scand. 1996;75(1):48-53.
33. Akyol D, Mungan T, Unsal A, Yüksel K. Prelabour rupture of the membranes at term-no advantage of delaying induction for 24 hours. Aust N Z J Obstet Gynaecol. 1999;39(3):291-5.

34. Hodnett ED, Hannah ME, Weston JA, Ohlsson A, Myhr TL, Wang EE, et al. Women's evaluations of induction of labor versus expectant management for prelabor rupture of the membranes at term. Term PROM Study Group. Birth Berkeley Calif. 1997;24(4):214-20.

35. McCaul JF, Rogers LW, Perry KG, Martin RW, Allbert JR, Morrison JC. Premature rupture of membranes at term with an unfavorable cervix: comparison of expectant management, vaginal prostaglandin, and oxytocin induction. South Med J. 1997;90(12):1229-33.

36. Ben-Haroush A, Yogev Y, Glickman H, Bar J, Kaplan B, Hod M. Mode of delivery in pregnancies with premature rupture of membranes at or before term following induction of labor with vaginal prostaglandin E2. Am J Perinatol. 2004;21(5):263-8.

37. Ezra Y, Michaelson-Cohen R, Abramov Y, Rojansky N. Prelabor rupture of the membranes at term: when to induce labor? Eur J Obstet Gynecol Reprod Biol. 2004;115(1):23-7.

38. da Graça Krupa F, Cecatti JG, de Castro Surita FG, Milanez HMBP, Parpinelli MA. Misoprostol versus expectant management in premature rupture of membranes at term. BJOG Int J Obstet Gynaecol. 2005;112(9):1284-90.

39. Lin MG, Nuthalapaty FS, Carver AR, Case AS, Ramsey PS. Misoprostol for labor induction in women with term premature rupture of membranes: a meta-analysis. Obstet Gynecol. 2005;106(3):593601.

40. Dare MR, Middleton P, Crowther CA, Flenady VJ, Varatharaju B. Planned early birth versus expectant management (waiting) for prelabour rupture of membranes at term (37 weeks or more). Cochrane Database Syst Rev. 2006;(1):CD005302.

41. Ayaz A, Saeed S, Farooq MU, Ahmad F, Bahoo LA, Ahmad I. Pre-labor rupture of membranes at term in patients with an unfavorable cervix: active versus conservative management. Taiwan J Obstet Gynecol. 2008;47(2):192-6.

42. Shanthi K, Devi PG, Bharathi T, Chandrasekharan PA. Comparative study of active versus expectant management and maternal and neonatal outcome in premature rupture of the membranes (PROM) in Tertiary Care Hospital, Tirupathi. IOSR-JDMS. 2015;14(4):34-9.

43. El Fekih C, Ouerdiane N, Mrezguia C, Mourali M, Douagi M, Abdennebi M, et al. Premature rupture membrane at term with unfavourable cervix. Tunis Médicale. 2009;87(9):603-6.

44. J V, G V. A Study of feto-maternal outcome in patients with prelabour rupture of membranes at term and gt;37 Weeks. Med Sci Int Med J. 2012;1(2):118. 
45. Shah K, Doshi H. Premature rupture of membrane at term: early induction versus expectant management. J Obstet Gynecol India. 2012;62(2):172-5.

46. Mbaluka CM, Kamau K, Karanja JG, Mugo N. Effectiveness and safety of 2-hourly $20 \mathrm{mcg}$ oral misoprostol solutions compared to standard intravenous oxytocin in labour induction due to prelabour rupture of membranes at term: a randomised clinical trial at kenyatta national hospital. East Afr Med J. 2014;91(9):303-10.

47. Pintucci A, Meregalli V, Colombo P, Fiorilli A. Premature rupture of membranes at term in low risk women: how long should we wait in the latent phase? J Perinat Med. 2014;42(2):189-96.

48. Sadeh-Mestechkin D, Samara N, Wiser A, Markovitch O, Shechter-Maor G, Biron-Shental T. Premature rupture of the membranes at term: time to reevaluate the management. Arch Gynecol Obstet. 2016.

49. Chaudhuri S, Kumar BP, Bhattacharyya S, Nath M. Premature rupture of membranes at term : immediate induction with PGE2 gel compared with delayed induction with oxytocin. J Obstet Gynecol India. 2006;56(3).

50. Yaqub U. Obstetric and perinatal outcome in induction of labor compared with expectant management for prelabor rupture of the membranes at term. Mushtaq R, editor. Pak Armed Forces Med J. 2015;65(2):179-83.

Cite this article as: Mukharya J, Mukharya S.

Comparative study of fetal and maternal outcomes of prelabour rupture of membranes at term. Int J Reprod Contracept Obstet Gynecol 2017;6:149-63. 